\title{
Presence in the Intestinal Lumen of Marine Fish of Corpuscles with a High Cadmium-, Zinc- and Copper-Binding Capacity: A Possible Mechanism of Heavy Metal Tolerance
}

\author{
F. Noël-Lambot \\ Laboratory of Oceanology, Institute of Chemistry, University of Liège, B 4000 Liège - Sart Tilman, Belgium
}

\begin{abstract}
In various species of unfed fish (Anguilla anguilla, Myoxocephalus scorpius, Serranus cabrilla, Moena chryselis, Scorpaena sp.), white mucous corpuscles were observed in the intestinal lumen. This material is regularly evacuated. The corpuscles contain high concentrations of $\mathrm{Ca}$ and $\mathrm{Mg}$; these elements are probably present in the form of carbonates precipitated from sea water contained in the intestine. In fish intoxicated with $\mathrm{CdCl}_{2}, \mathrm{ZnCl}_{2}$ or $\mathrm{CuCl}_{2}$ added to sea water, the corpuscles contain enormous concentrations of these metals; although the weight of the corpuscles is small (about $0.1 \%$ of the total wet weight of Anguilla anguilla), they may contain most of the Cd body burden. Corpuscles from non-intoxicated fish bind heavy metals in vitro: exposed to $\mathrm{Cd}$, Zn or Cu enriched solutions, they retain these metals to the same extent as in vivo. It thus appears that metals are accumulated in the corpuscles directly from ingested sea water with a reduction in respective metal concentrations of the intestinal liquid. Intestinal corpuscles seem therefore to limit the entry of metals through the intestinal wall and to protect the fish against potentially hazardous concentrations of heavy metals
\end{abstract}

\section{INTRODUCTION}

In context with experimental studies of Cd accumulation in the eel Anguilla anguilla (Noël-Lambot and Bouquegneau, 1977; Noël-Lambot et al., 1978) we observed in the intestinal lumen of unfed fish, white mucous corpuscles with a very high $\mathrm{Cd}$ content. This material, regularly evacuated through the anus, was termed 'intestinal corpuscles'. The nature of this material and the mechanisms of $\mathrm{Cd}$-, $\mathrm{Zn}$ - and $\mathrm{Cu}$-binding in eels and other teleost species have been investigated.

\section{MATERIAL AND METHODS}

Individuals of the fish species Anguilla anguilla, Myoxocephalus scorpius, Serranus cabrilla, Moena chryselis and Scorpaena sp. were placed in polyethylene bags containing aerated natural sea water (5l ind.-1) to which various doses of $\mathrm{CdCl}_{2}, \mathrm{ZnCl}_{2}$ and/or $\mathrm{CuCl}_{2}$ were added. Before intoxication, freshwater eels (45 to $60 \mathrm{~cm}$ in length) were adapted for 1 week to sea water. The water was changed daily; its temperature was about $18^{\circ} \mathrm{C}$. Its initial content in heavy metals

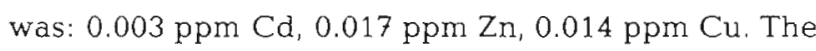
fish were not fed.

Stomach and intestine were clamped by means of artery clips, cut off and their contents were collected. Intestinal corpuscles were separated manually from the intestinal liquid and then stored in a deep freezer or analysed immediately.

$\mathrm{Cd}$ and $\mathrm{Ca}$ analyses were made by atomic absorption spectrophotometry (A.A.S., Perkin Elmer, Model 103) after mineralization for $12 \mathrm{~h}$ at $80^{\circ} \mathrm{C}$ in $65 \% \mathrm{HNO}_{3}$ (2.5 $\mathrm{ml} \mathrm{HNO}_{3} \mathrm{~g}^{-1}$ wet weight) and twentyfold dilution. Owing to the high $\mathrm{Ca}$ and $\mathrm{Na}$ content of the intestinal corpuscles and the interference of both elements with Cd determination by A.A.S. (Pulido et al., 1966; Friberg et al., 1974), this method was only used for samples of corpuscles with $\mathrm{Cd}$ concentration higher than $4 \mathrm{ppm}$ w.wt. Corpuscles with lower Cd concentrations were analysed by anodic stripping voltammetry (MASA-2014 ESA) after ashing with microwave activated oxygen (calcinator Tracerlab 600) and dissolution in concentrated $\mathrm{HCl}$ (Gillain and Duyckaerts, 1977). One sample of intestinal corpuscles was also analysed by spark source mass spectrography (AEI, type MS702R) following the method described by Gauneau (1975). 


\section{RESULTS}

\section{Nature of Intestinal Corpuscles}

The material named 'intestinal corpuscles' was observed in unfed fish living in natural sea water enriched, or not, with heavy metals. Absent in eels living in fresh water, it appears in the first hours after transfer into sea water. The intestinal corpuscles consist of tangled white threads enveloped in a material of mucous (Figs 1 and 2). They are exclusively found in shows that intestinal corpuscles consist of granules (about $1 \mu \mathrm{m}$ in diameter). These granules are very abundant in the chalky portions of the corpuscles, whereas in the mucous portions they are grouped in scattered islets. These granules, which are the main constituents of the corpuscles, remain unaltered during prolonged conservation (several months) at room temperature. The granules have a high carbonate content as indicated by their disappearance accompanied by a gas emission upon treatment by acids. In the intestinal corpuscles formed in the eels during the first

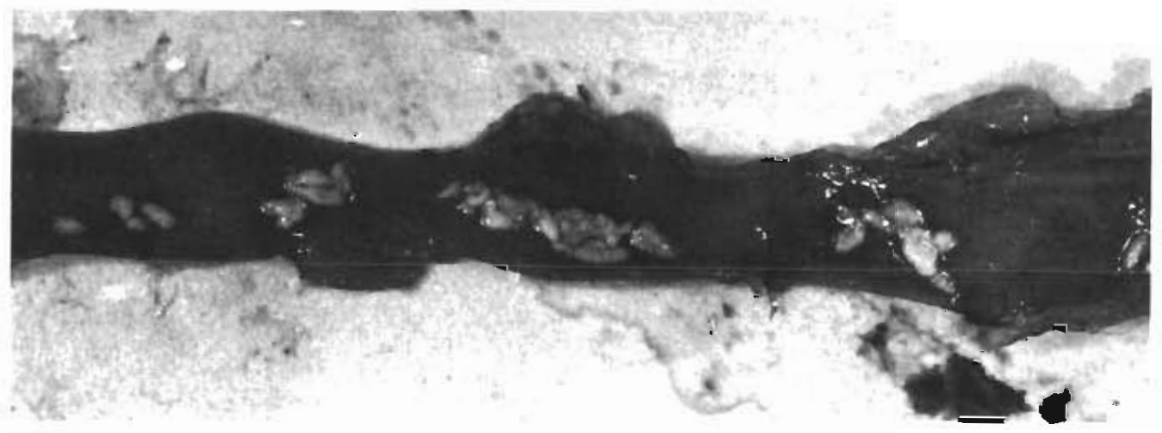

Fig. 1. Anguilla anguilla. Longitudinal section of intestine showing intestinal corpuscles $(1.5 \times)$

the intestinal lumen or in the surrounding water where they are eliminated. Often, their appearance changes according to the part of the intestine occupied: mucoid corpuscles predominate in the anterior intestine, chalky corpuscles in the posterior region (in Fig. 2 both materials occur in the same corpuscle).

Organic matter is not an abundant constitutent of the corpuscles as indicated by the small weight loss during calcination of the dry matter. Microscopic examination

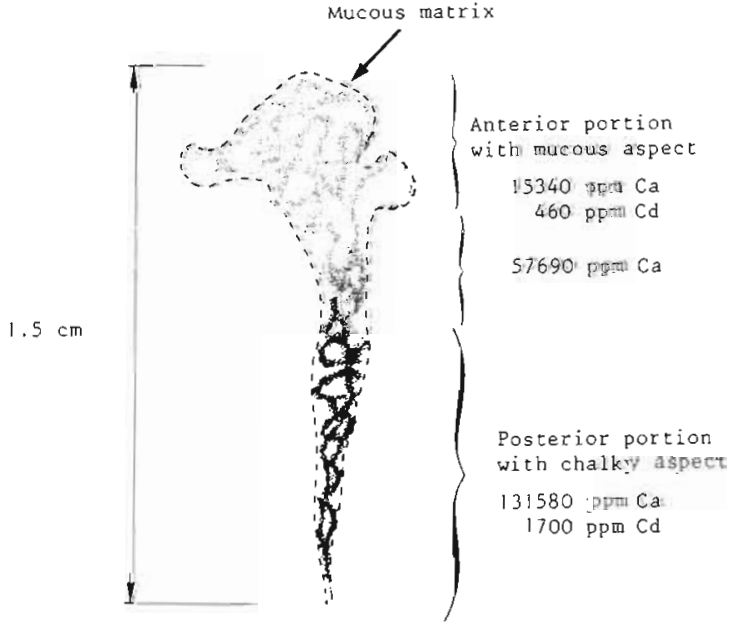

Fig. 2. Anguilla anguilla. Intestinal corpuscle of an individual exposed for $4 \mathrm{~d}$ to sea water containing $13 \mathrm{ppm} \mathrm{Cd}$. Ca and Cd concentrations (ppm w.wt.) are given for various parts
Table 1. Anguilla anguilla. Analysis of intestinal corpuscles from individuals living in natural sea water

\begin{tabular}{|crc|}
\hline Element & ppm dr.wt. & ppm w.wt. \\
\hline $\mathrm{Mg}$ & 126000 & \\
$\mathrm{Ca}$ & 75000 & \\
$\mathrm{Na}$ & 20500 & \\
$\mathrm{~S}$ & 5400 & \\
$\mathrm{~K}$ & 1300 & \\
$\mathrm{Sr}$ & 700 & \\
$\mathrm{P}$ & 600 & \\
$\mathrm{Si}$ & 150 & \\
$\mathrm{As}$ & 74 & \\
$\mathrm{Zn}$ & 46 & \\
$\mathrm{Ti}$ & 31 & \\
$\mathrm{Fe}$ & 27 & \\
$\mathrm{~F}$ & 20 & \\
$\mathrm{Cu}$ & $-27(\mathrm{~m}=20)$ \\
$\mathrm{Al}$ & - & $3-12(\mathrm{~m}=7)$ \\
$\mathrm{Cr}$ & 15 & \\
$\mathrm{Br}$ & 11 & \\
$\mathrm{~Pb}$ & 10 & $0.3-0.5(\mathrm{~m}=0.4)$ \\
$\mathrm{Ba}$ & - & \\
$\mathrm{Sb}$ & 5 & \\
$\mathrm{Cd}$ & 4 & \\
Mass spectrography analysis $(\mathrm{n}=1)$ & \\
Anodic stripping voltammetry analysis $(\mathrm{n}=4)$ & \\
\hline
\end{tabular}

hours following transfer to sea water, next to the granules one can observe some crystals, probably of calcite (average size: $0.1 \mathrm{~mm}$ ).

Table 1 lists the results of mass spectrography and 
Table 2. Anguilla anguilla. Cd concentration of intestinal corpuscles from individuals intoxicated for $8 \mathrm{~d}$ or more (see text) in sea water plus $\mathrm{CdCl}_{2}$

\begin{tabular}{|c|c|c|c|c|}
\hline \multirow[t]{2}{*}{ Cd in water (ppm) } & \multirow[t]{2}{*}{$\mathrm{n}$} & \multicolumn{2}{|c|}{ Cd in corpuscles (ppm w.wt.) } & \multirow{2}{*}{$\begin{array}{c}\text { Maximum } \\
\text { concentration factor }\end{array}$} \\
\hline & & Extreme values & Mean & \\
\hline 0.003 & 4 & $0.3-$ & 0.4 & 167 \\
\hline 0.020 & 2 & $2.9-$ & 3.0 & 155 \\
\hline 0.060 & 2 & $1.8-$ & 2.6 & 58 \\
\hline 0.13 & 7 & $5.0-27.0$ & 22.0 & 207 \\
\hline 1.00 & 4 & $7.0-71.0$ & 55.0 & 71 \\
\hline 13.00 & 7 & $141.0-1700.0$ & 396.0 & 131 \\
\hline 100.0 & 7 & $33.0-3397.0$ & 942.0 & 34 \\
\hline
\end{tabular}

Table 3. Scorpaena sp. Cd, Zn and Cu concentrations of intestinal corpuscles from scorpionfish in absence of intoxication or after $1 \mathrm{~d}$ intoxication in sea water containing $1 \mathrm{ppm}$ of $\mathrm{Cd}, 1 \mathrm{ppm}$ of $\mathrm{Zn}$ and $1 \mathrm{ppm}$ of $\mathrm{Cu}$

\begin{tabular}{|c|c|c|c|c|c|c|}
\hline Condition & \multicolumn{3}{|c|}{ (ppm w.wt.) } & \multicolumn{3}{|c|}{ (ppm dr.wt.) } \\
\hline Control & $<1$ & 25.3 & 4.5 & $<4$ & 94.9 & 16.9 \\
\hline $1 \mathrm{~d}$ intoxication & 99.0 & 158.6 & 78.6 & 220.3 & 353.1 & 175.0 \\
\hline
\end{tabular}

Table 4. Anguilla anguilla. Cd distribution in individuals intoxicated for $8 \mathrm{~d}$ in sea water containing $13 \mathrm{ppm} \mathrm{Cd}(\mathrm{n}=4)$

\begin{tabular}{|c|c|c|c|}
\hline Organs & $\begin{array}{l}\text { Weight of } \\
\text { organs } \\
\text { (g) }\end{array}$ & $\begin{array}{c}\text { Cd conc. } \\
\text { (ppm or } \\
\mu \mathrm{g} \mathrm{g}^{-!} \text {w.wt.) }\end{array}$ & $\begin{array}{c}\text { Cd load } \\
(\mu \mathrm{g})^{\circ}\end{array}$ \\
\hline Muscles & 75.5 & 0.2 & 18.9 \\
\hline Skin & 10.6 & 0.6 & 6.9 \\
\hline Bones & 6.6 & 0.2 & 1.6 \\
\hline Digestive tract & 2.1 & 4.8 & 10.1 \\
\hline Liver & 1.2 & 10.3 & 12.4 \\
\hline Kidneys & 0.7 & 5.7 & 4.0 \\
\hline Fat & 0.7 & 0.3 & 0.2 \\
\hline Plasma & 0.6 & 0.8 & 0.5 \\
\hline Gills & 0.5 & 4.0 & 2.0 \\
\hline Intestinal fluid & 0.4 & 3.0 & 1.2 \\
\hline Blood cells & 0.3 & - & - \\
\hline Spleen & 0.2 & - & - \\
\hline Air bladder & 0.2 & - & - \\
\hline Bile & 0.1 & 0.4 & $<0.1$ \\
\hline Heart & 0.1 & - & - \\
\hline Gastric fluid & 0.1 & 10.0 & 1.0 \\
\hline $\begin{array}{l}\text { Intestinal } \\
\quad \text { corpuscles }\end{array}$ & 0.1 & 396.0 & 39.6 \\
\hline Total & 100.0 & 0.98 & 98.5 \\
\hline \multicolumn{4}{|c|}{$\begin{array}{l}\text { - From metal concentrations in different organs and from } \\
\text { weight fractions of these organs, the metal load (expressed } \\
\text { in } \mu \mathrm{g} \text { ) of each organ can be calculated for a fish whose } \\
\text { weight is reduced to } 100 \mathrm{~g} \text {. The total body load is deter- } \\
\text { mined by summation of the load of each organ }\end{array}$} \\
\hline
\end{tabular}

anodic stripping voltammetry (ASV) analyses of intestinal corpuscles of eels from unpolluted sea water. Concentrations of $\mathrm{Mg}$ and $\mathrm{Ca}$ are high and some metals, present as traces in sea water, are found at comparatively high concentrations: $\mathrm{As}, \mathrm{Al}, \mathrm{Cd}, \mathrm{Cr}, \mathrm{Cu}, \mathrm{Fe}$, $\mathrm{P}, \mathrm{Pb}, \mathrm{Sb}, \mathrm{Ti}, \mathrm{Zn}$.

A.A.S. analyses confirm the existence of high concentrations of $\mathrm{Ca}$ in the intestinal corpuscles, especially in their more opaque areas (Fig. 2), which is where the microgranules are most numerous. The variations of $\mathrm{Cd}$ concentrations in the corpuscles of intoxicated eels follow approximately those of Ca (Fig. 2). This probably explains the pronounced differences between $\mathrm{Cd}$ concentrations in corpuscles collected in identical conditions (Table 2).

\section{Heavy Metals Accumulation in Intestinal Corpuscles}

Metal concentrations in the intestinal corpuscles from fish submitted for $1 \mathrm{~d}$ or longer to different $\mathrm{Cd}, \mathrm{Zn}$ and $\mathrm{Cu}$ concentrations are shown in Tables 2 and 3. Metal concentrations in the corpuscles similar to those presented in Tables 2 and 3 are already attained during the first hours of intoxication (see below). They then remain nearly constant during intoxication and decline rapidly after the fish are returned to clean water.

Cd concentrations in intestinal corpuscles from intoxicated fish are generally higher than in any other organ. This is why, in spite of their low weight (ca $0.1 \mathrm{~g}$ ), the intestinal corpuscles account for a large fraction of the total $\mathrm{Cd}$ content in the fish. The study of $\mathrm{Cd}$ distribution in the different organs of eels during experimental intoxication shows that after $8 \mathrm{~d}$ in sea water containing $13 \mathrm{ppm} \mathrm{Cd}$, the intestinal corpuscles contain almost as much $\mathrm{Cd}$ as do the remaining body parts (Table 4; see also Noël-Lambot and Bouquegneau, 1977). 


\section{Origin of Cd Found in Intestinal Corpuscles of Anguilla anguilla}

It is assumed that the $\mathrm{Cd}$ present in the intestinal corpuscles originates either directly from the sea water ingested or is excreted through the digestive barrier. The second hypothesis postulates a mechanism other than $\mathrm{Cd}$ elimination in the bile because the latter is not sufficient to account for the high $\mathrm{Cd}$ contents of the intestinal corpuscles (Table 4).

Table 5. Anguilla anguilla. Mean Cd concentration of intestinal corpuscles, taken from untoxicated individuals and then placed for $6 \mathrm{~h}$ in sea water or distilled water plus $\mathrm{CdCl}_{2}$. Corpuscles were quickly rinsed with distilled water before being analysed

\begin{tabular}{|lccc|}
\hline Type of water & $\begin{array}{c}\text { Cd in water } \\
(\mathrm{ppm})\end{array}$ & $\mathrm{n}$ & $\begin{array}{c}\text { Cd in } \\
\text { corpuscles } \\
\text { (ppm w.wt.) }\end{array}$ \\
\hline Sea water & 0.06 & 2 & 3 \\
Distilled water & 0.90 & 1 & 88 \\
Sea water & 0.90 & 3 & 89 \\
Distilled water & 90.00 & 7 & 2188 \\
\hline
\end{tabular}

Table 5 indicates that, in vitro, the intestinal corpuscles rapidly bind $\mathrm{Cd}^{2+}$ ions present in sea water or in distilled water. Compared to Table 2, Table 5 indicates that $\mathrm{Cd}$ accumulation in the intestinal corpuscles is as important in vitro as in vivo for similar external $\mathrm{Cd}$ concentrations.

Table 6 reveals that, in the case of short intoxication, high $\mathrm{Cd}$ concentrations in the corpuscles are attained,

Table 6. Anguilla anguilla. Cd concentrations in organs after brief intoxication in sea water plus $\mathrm{CdCl}_{2}$

\begin{tabular}{|c|c|c|c|}
\hline Material & $\begin{array}{c}6 \mathrm{~h} \text { in } \\
1 \mathrm{ppm} \mathrm{Cd} \\
\mathrm{n}=3\end{array}$ & $\begin{array}{c}2 \mathrm{~h} \text { in } \\
100 \mathrm{ppm} \mathrm{Cd} \\
\mathrm{n}=2\end{array}$ & $\begin{array}{c}6 \mathrm{~h} \text { in } \\
100 \mathrm{ppm} \mathrm{Cd} \\
\mathrm{n}=2\end{array}$ \\
\hline Muscles & - & - & 0.6 \\
\hline Skin & - & - & 1.5 \\
\hline Oesophagus & - & - & 2.7 \\
\hline Stomach & - & - & 1.7 \\
\hline Duodenum & - & - & 1.4 \\
\hline Liver & - & - & 3.2 \\
\hline Kidneys & - & - & 2.2 \\
\hline Blood & - & - & 2.6 \\
\hline Gills & - & -- & 3.4 \\
\hline Brain & - & - & 0.5 \\
\hline Total body & - & - & 0.8 \\
\hline \multicolumn{4}{|l|}{ Intestinal } \\
\hline corpuscles & 55.4 & $231-3400$ & $33-3000$ \\
\hline Gastric fluid & 0.8 & 54.4 & 44.5 \\
\hline Intestinal fluid & 0.15 & 2.7 & 1.3 \\
\hline
\end{tabular}

although the metal penetrates the body only in minute amounts. It therefore seems improbable that a mechanism to eliminate the pollutant is already operative. Experiments involving intramuscular $\mathrm{CdCl}_{2}$ injections prove that the $\mathrm{Cd}$ in intestinal corpuscles does not result from an excretory process. Indeed, in that case only very small amounts of $\mathrm{Cd}$ are found in the corpuscles (Table 7).

Table 7. Anguilla anguilla. Distribution of $\mathrm{Cd} 60 \mathrm{~h}$ after single intramuscular injection of $800 \mu \mathrm{g} \mathrm{Cd}$. Means of 2 individuals. Weight of each individual: $170 \mathrm{~g}$

\begin{tabular}{|lc|}
\hline Material & Cd (ppm w.wt.) \\
\hline Muscles & 1.0 \\
Skin & 3.7 \\
Oesophagus & 4.9 \\
Stomach & 6.4 \\
Duodenum & 23.9 \\
Intestine & 8.1 \\
Liver & 132.5 \\
Bile & 10.6 \\
Kidneys & 38.8 \\
Fat & 3.4 \\
Plasma & 11.8 \\
Blood cells & 6.2 \\
Gills & 15.0 \\
Spleen & 24.0 \\
Brain & 1.2 \\
Intestinal fluid & 1.2 \\
Intestinal corpuscles & $<5$ \\
\hline
\end{tabular}

All this information indicates that the $\mathrm{Cd}$ found in intestinal corpuscles mainly comes from the water ingested by the fish. This important fixation on the corpuscles reduces the $\mathrm{Cd}$ content in the water inside the intestine. Tables 4 and 6 show that the $\mathrm{Cd}$ concentration in the gastric fluid is only slightly less than in sea water, but that intestinal-fluid concentration is much smaller. This significant lowering of the $\mathrm{Cd}$ concentration in the fluid in contact with the intestinal wall probably limits the amount of metal absorption at this level.

Figure 3 illustrates and quantifies this fixation of $\mathrm{Cd}$ on the corpuscles of the eel and its consequences for $\mathrm{Cd}$ distribution in the digestive lumen. After a $6-\mathrm{h}$ exposure to $100 \mathrm{ppm} \mathrm{Cd}$, the intestinal corpuscles retain more than $99 \%$ of the $\mathrm{Cd}$ present in the intestinal lumen. This amount of trapped $\mathrm{Cd}$ is even greater than the total $\mathrm{Cd}$ accumulated by all the tissues of the eel during $6 \mathrm{~h}$ of intoxication. Indeed the total body load calculated from the $\mathrm{Cd}$ concentrations in the different organs (Table 6 ) is $78.5 \mu \mathrm{g} \mathrm{Cd}$ for eels weighing $100 \mathrm{~g}$. If the $\mathrm{Cd}$ body load prior to intoxication (Noël-Lambot, 1980) is subtracted from this value, one obtains a $\mathrm{Cd}$ accumulation of $78.5 \mu \mathrm{g}-15 \mu \mathrm{g}$ 


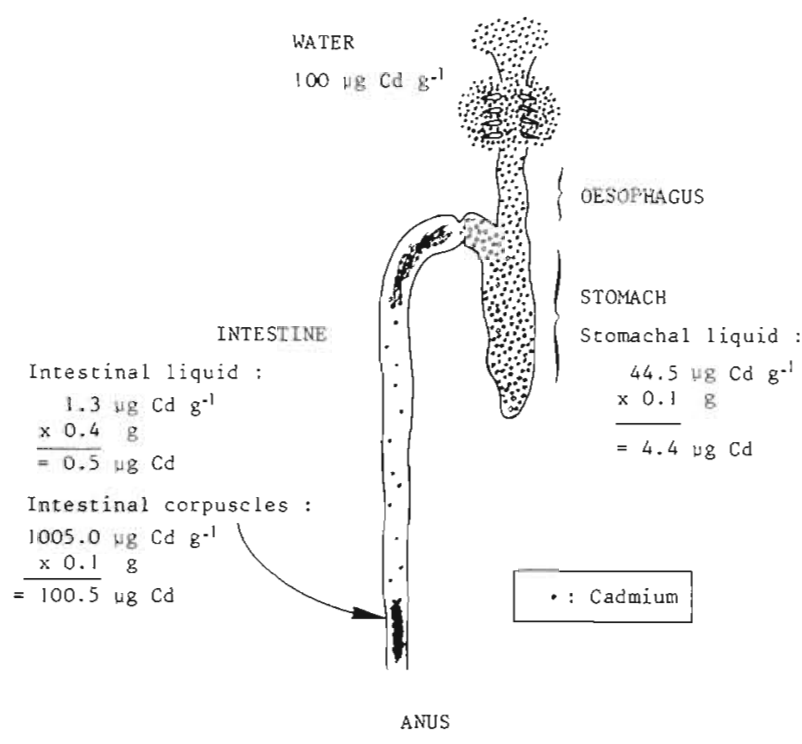

Fig. 3. Anguilla anguilla. Cd concentration inside the digestive tract of individuals intoxicated during a 6 -h exposure to sea water containing $100 \mathrm{ppm} \mathrm{Cd}$. For each constituent the Cd concentration ( $\mathrm{ppm}=\mu \mathrm{g} \mathrm{g}^{-1}$ ) is given, as well as the load $(\mu \mathrm{g})$ equal to the product of the concentration and the weight of the constituent considered. The loads are calculated for eels whose weight is adjusted to $100 \mathrm{~g}$

$=63.5 \mu \mathrm{g}$; now $100.5 \mu \mathrm{g}$ Cd are trapped in the corpuscles (Fig. 3).

Since $\mathrm{CaCO}_{3}$ is an important constituent of the intestinal corpuscles, it was interesting to find out its binding capacity toward $\mathrm{Cd}$. We could observe this was of the same order of magnitude as that of the intestinal corpuscles. Indeed, when amorphous $\mathrm{CaCO}_{3}$ precipitate (calcium carbonate precipitate, for analysis of silicates, MERCK) is immersed in a $\mathrm{CdCl}_{2}$ solution, an important part of the Cd can be found in the precipitate (Table 8).

\section{DISCUSSION AND CONCLUSIONS}

The results described in this paper principally concern Anguilla anguilla, but we could observe similar corpuscles in all the teleosts we investigated: Myoxocephalus scorpius, Serranus cabrilla, Scorpaena sp., Moena chryselis.

Gardner and Yevich (1970) observed during lethal intoxication of the euryhaline fish Fundulus heteroclitus - in sea water containing $50 \mathrm{ppm} \mathrm{Cd} \mathrm{-} \mathrm{elimina-}$ tion through the anus of a 'white mucoid material, tubular in shape. Microscopic examination of this anal exudate indicated a mucous mass containing cellular debris'. The Cd content of this material was not measured. To our knowledge, this is the only information on our subject in literature.

The formation of intestinal corpuscles can probably be explained by precipitation of salts - mainly $\mathrm{Mg}$ and Ca carbonates - present in water swallowed by the fish, on an organic support made of mucus and cellular debris. Indeed, as $\mathrm{Ca}$ concentrations in the gastric and intestinal walls are very low (89 and 44 ppm respectively) it seems improbable that the $\mathrm{Ca}$ found in the corpuscles has been secreted through the digestive mucosa. High intestinal $\mathrm{pH}$ probably plays a role in carbonate precipitation: the $\mathrm{pH}$ of eel gastric and intestinal fluids is 6.5 and 8.5 respectively. Such high $\mathrm{pH}$ of the sea water contained in the intestine modifies the dissociation equilibrium of carbonic acid (Riley and Chester, 1971) and enhances the precipitation of low-solubility carbonates. It must be pointed out that most surface sea waters are oversaturated in $\mathrm{CaCO}_{3}$ (Pytkowicz, 1965) and also that the water volume ingested by sea fish is large, water absorption in the intestine compensating the loss of water resulting from hypotonicity (e. g. Maetz, 1971).

Gardner and Yevich (1970) observed an increase in mucous cell activity in the intestinal tract of fish after $\mathrm{Cd}$ exposure. It is therefore possible that formation of intestinal corpuscles could be more abundant in the presence of $\mathrm{Cd}$. This would then constitute an interesting protective mechanism against intoxication by heavy metals (see also below).

We have shown that the intestinal corpuscles bind very rapidly cadmium and some other heavy metals present in the ingested water. It seems that this bind-

Table 8. Distribution of $\mathrm{Cd}$ between liquid and solid phases of a suspension of $\mathrm{CaCO}_{3}$ in distilled water (D.W.) or sea water (S.W.) containing $1 \mathrm{ppm} \mathrm{Cd} . \mathrm{CaCO}_{3}$ precipitate was immersed for $2 \mathrm{~d}$ in $50 \mathrm{ml}$ of a $\mathrm{CdCl}_{2}$ solution; the mixture was intermittently stirred and then filtered; $\mathrm{Cd}$ was measured in the filtrate and in the precipitate; $\mathrm{pH}$ of the mixture was measured at the beginning and at the end of the experiment. This experiment was repeated

\begin{tabular}{|lcccc|}
\hline Nature of the mixture & $\begin{array}{c}\mathrm{Cd} \text { in water } \\
(\mu \mathrm{g})\end{array}$ & $\begin{array}{c}\mathrm{Cd} \text { in precipitate } \\
(\mu \mathrm{g})\end{array}$ & $\mathrm{t}_{0}$ & $\mathrm{t}_{2}$ \\
\hline $1 \mathrm{ppm} \mathrm{Cd}$ in D.W. & 50.0 & & 5.58 & - \\
$1 \mathrm{ppm} \mathrm{Cd} \mathrm{in} \mathrm{D.W.}+2 \mathrm{~g} \mathrm{CaCO}_{3}$ & $<0.5$ & 50.4 & 9.60 & 8.50 \\
$1 \mathrm{ppm} \mathrm{Cd}$ in S.W. & 50.0 & & 7.96 & - \\
$1 \mathrm{ppm} \mathrm{Cd}$ in S.W. $+0.5 \mathrm{~g} \mathrm{CaCO}_{3}$ & 33.7 & 16.6 & 7.99 & 8.29 \\
$1 \mathrm{ppm} \mathrm{Cd}$ in S.W. $+2 \mathrm{~g} \mathrm{CaCO}_{3}$ & 15.0 & 33.6 & 7.99 & 8.22 \\
\hline
\end{tabular}


ing takes place in the inorganic constituents of the corpuscles. Indeed we have established that the mineral portions of the intestinal corpuscles contained higher $\mathrm{Cd}$ concentrations than the mucous portions and that $\mathrm{CaCO}_{3}$ precipitates had a high affinity for cadmium ions. The important accumulation of heavy metals in intestinal corpuscles can probably be explained by interactions - for instance adsorption, ionic exchange or complexation - between cadmium ions and some mineral constituents of the corpuscles. Complexation of $\mathrm{Cd}^{2+}$ by carbonates has been described by Lake and Goodings (1958) and by Gardiner (1974). The possible precipitation of cadmium as carbonate on the organic support of the corpuscles or its coprecipitation with carbonate minerals must also be considered, because of the low solubility of this salt and the alkaline $\mathrm{pH}$ of the intestinal fluid.

A similar mechanism has been proposed by Salomon and Mook (1978, cited by Förstner, 1979) who observed in the transition region from the Rhine to the Ijssel Sea in Holland, that a decrease of the dissolved loads of $\mathrm{Zn}$, $\mathrm{Cd}$ and $\mathrm{Ni}$ is directly dependent on the precipitation of carbonate minerals, which is chiefly a result of an increase in $\mathrm{pH}$. Coprecipitation experiments on calcium carbonates performed by Popova (1961, cited by Förstner, 1979) show that heavy metal carbonates of low solubility - such as $\mathrm{CdCO}_{3}, \mathrm{PbCO}_{3}$ and $\mathrm{ZnCO}_{3}-$ are completely eliminated from solution as a result of $\mathrm{CaCO}_{3}$ precipitation. Without a carrier substance, in this case $\mathrm{CaCO}_{3}$, the metal cations would not have been precipitated.

Cadmium fixation in the intestinal corpuscles lowers considerably the $\mathrm{Cd}$ content of the fluid next to the intestinal wall and thus probably limits its absorption by the mucosa. From this point of view, intestinal corpuscles constitute a protective mechanism against $\mathrm{Cd}$. Digestive absorption of $\mathrm{Cd}$ is extremely limited in all organisms studied so far (Kumada et al., 1972; Benayoun et al., 1974; Bouquegneau et al., 1976; Valberg et al., 1976). This element is thus found in high concentration in the feces. In fish, $\mathrm{Cd}$ fixation in the intestinal corpuscles probably contributes to this mechanism.

Moreover, in the same way as the exuvia of crustaceans (Martin, 1970; Benayoun et al., 1974), the fecal pellets of molluscs and crustaceans (Boothe and Knauer, 1972; Benayoun et al., 1974) or the feces of tunicates that can contain as much as $1500 \mathrm{ppm} \mathrm{Cd}$ w.wt. for $0.5 \mathrm{ppm} C d$ in sea water (Noël-Lambot, unpubl.), the intestinal corpuscles from fish may play an important role in the vertical transfer of $\mathrm{Cd}$ and other heavy metals in the marine environment.
Acknowledgements. I am grateful to Professor A. Distèche for his advice throughout this work. I thank Mr G. Gillain for A.S.V. analyses, Mrs L. Carolo and Mr F. Leyder for mass spectrometry analyses, Mrs G. Jamsin and Mr R. Biondo for technical assistance and Mrs C. Marchand for typing the manuscript.

This work is a contribution of the Belgian National Research and Development Program on the EnvironmentWater-Sea Project (Office of the Prime Minister, Interministerial Commission for Science Policy and Programmation) and to the Concerted Oceanological Actions of the Belgian Universities.

\section{LITERATURE CITED}

Benayoun, G., Fowler, S. W., Oregioni, B. (1974). Flux of cadmium through Euphausiids. Mar. Biol. 27: 205-212

Boothe, P. N., Knauer, G. A. (1972). The possible importance of fecal material in the biological amplification of trace and heavy metals. Limnol. Oceanogr. 17: 270-274

Bouquegneau, J. M., Noël-Lambot, F., Distèche, A. (1976). Le problème de l'intoxication directe et indirecte par les métaux lourds. In: Nihoul, J, C. J., Distèche, A. (ed.) Programme National Belge de Recherche et de Développement - Projet Mer - Rapport final, Vol. 9, Contamination des produits de la mer, Services du Premier Ministre, Programmation de la Politique Scientifique, Bruxelles, 266-292

Förstner, U. (1979). Metal transfer between solid and aqueous phases. In: Förstner, U., Wittmann, G. T. W. (ed.) Metal pollution in the aquatic environment. Springer-Verlag, Berlin, Heidelberg, New York, pp. 197-270

Friberg, L., Piscator, M., Nordberg, G. F., Kjellström, T. (1974). Cadmium in the environment, 2nd ed., CRC Press, Cleveland

Gardiner, J. (1974). The chemistry of cadmium in natural water. I. A study of cadmium complex formation using the cadmium specific-ion electrode. Wat. Res. 8: 23-30

Gardner, G. R., Yevich, P. P. (1970). Histological and hematological responses of an estuarine Teleost to cadmium. J. Fish. Res. Bd Can. 27: 2185-2196

Gauneau, M. (1975). Emploi d'électrodes auxiliaires pour l'analyse des éléments de transition dans les verres et silices très purs par spectrographie de masse à étincelles. Analusis 3: $368-375$

Gillain, G., Duyckaerts, G. (1977). Evaluation et comparaison de quelques méthodes de dosage de métaux lourds dans le plancton. In: Recherche et technique au service de l'environnement. CEBEDOC, Liège, Belgique pp. 347-360

Kumada, H., Kimura, S., Yokote, M., Matida, Y. (1972). Acute and chronic toxicity, uptake and retention of $\mathrm{Cd}$ in freshwater organisms. Bull. Freshwat. Fish. Res. Lab. 22: $157-165$

Lake, P. E., Goodings, J. M. (1958). The nature of the cadmium ions in hydroxide and carbonate solutions. Can. J. Chem. 36: 1089-1096

Maetz, J. (1971). Fish gills: mechanisms of salt transfer in fresh water and sea water. Phil. Trans. R. Soc. (B) 262: 209-249

Martin, J. H. (1970). The possible transport of trace metals via moulted copepod exoskeletons. Limnol. Oceanogr. 15: $756-761$

Noël-Lambot, F. (1980). La bioaccumulation du cadmium en milieu marin. Thèse de doctorat, Université de Liège, Belgique, University Microfilms International, Ann Arbor, Michigan, 1980 
Noël-Lambot, F., Bouquegneau, J. M. (1977). Comparative study of toxicity, uptake and distribution of $\mathrm{Cd}$ and $\mathrm{Hg}$ in the eel Anguilla anguilla. Bull. environm. Contam. Toxicol. 18: 418-424

Noël-Lambot, F., Gerday, Ch., Distèche, A. (1978). Distribution of $\mathrm{Cd}, \mathrm{Zn}$ and $\mathrm{Cu}$ in liver and gills of the eel Anguilla anguilla with special reference to metallothioneins. Comp. Biochem. Physiol. 61C: 177-187

Pulido, P., Fuwa, K., Vallee, B. L. (1966). Determination of cadmium in biological materials by A.A.S. Anal. Biochem. 14: $393-404$

Pytkowicz, R. M. (1965). Calcium carbonate saturation in the ocean. Limnol. Oceanogr. 10: 220-225

Riley, J. P., Chester, R. (1971). Introduction to marine chemistry, Academic Press, London, New York

Valberg, L. S., Sorbie, J., Hamilton, D. L. (1976). Gastrointestinal metabolism of $\mathrm{Cd}$ in experimental Fe deficiency. Am. J. Physiol. 231: 462-467

This paper was submitted to the editor; it was accepted for printing on December 10, 1980 